\title{
ANALISIS KETERAMPILAN DASAR MENGAJAR MAHASISWA CALON GURU KIMIA (STUDI PADA PRAKTIK PENGALAMAN LAPANGAN MAHASISWA TADRIS KIMIA)
}

\begin{abstract}
Mulyatun
ABSTRAK

Pembekalan praktis kependidikan bagi mahasiswa calon guru di LPTK mutlak diperlukan untuk meningkatkan kompetensi calon guru ketika terjun di dunia pendidikan. Pembekalan ini dapat dilakukan melalui berbagai kegiatan, diantaranya melalui praktik pengajaran secara mikro (microteaching) maupun melalui praktik mengajar secara riil di sekolah (Praktik Pengalaman Lapangan). Penelitian ini bertujuan untuk mengetahui tingkat penguasaan keterampilan dasar mengajar calon guru Tadris Kimia Fakultas Tarbiyah IAIN Walisongo pada kegiatan Praktik Pengalaman Lapangan (PPL).
\end{abstract}

Penelitian dilaksanakan di Program Studi Tadris Kimia Fakultas Tarbiyah IAIN Walisongo Semarang dengan melibatkan mahasiswa Tadris Kimia yang mengambil mata kuliah Praktik Pengalaman Lapangan. Data diperoleh dengan metode observasi pada kegiatan pembelajaran di kelas oleh mahasiswa calon guru Kimia. Delapan keterampilan dasar mengajar mahasiswa diamati dan dianalisis pada pelaksanaan Praktik Pengalaman Lapangan meliputi (1) Keterampilan bertanya, (2) Keterampilan memberi penguatan, (3) Keterampilan mengadakan variasi, (4) Keterampilan menjelaskan, (5) Keterampilan membuka dan menutup pelajaran, (6) Keterampilan membimbing diskusi kelompok kecil, (7) Keterampilan mengelola kelas, (8) Keterampilan mengajar kelompok kecil dan perorangan.

Delapan keterampilan dasar mengajar Mahasiswa Tadris Kimia pada pelaksanaan PPL secara keseluruhan adalah baik dangan persentase penilaian mencapai 69,59\%. Keterampilan dasar mengajar mahasiswa Tadris Kimia yang paling menonjol adalah ketrampilan memberi penguatan $(74,14 \%)$, sedangkan ketrampilan yang paling rendah adalah keterampilan mengadakan variasi $(64,86 \%)$.

Kata kunci : Ketrampilan Dasar Mengajar, Calon Guru Kimia. 


\section{PENDAHULUAN}

Tersedianya tenaga pendidik (guru) profesional sesuai tuntutan Undang Undang Guru dan Dosen (2005), membawa implikasi bagi Lembaga Pendidikan Tenaga Kependidikan (LPTK). Dewasa ini LPTK dituntut mampu menghasilkan tenaga pendidik yang memiliki 4 kompetensi sekaligus meliputi: kompetensi profesional, kompetensi pedagogi, kompetensi sosial dan kompetensi kepribadian. Untuk memenuhi tuntutan tersebut, maka kurikulum LPTK harus senantiasa dikembangkan secara dinamis dan berkualitas, agar dapat membekali para calon guru secara memadai baik ditinjau dari aspek teori maupun praktis kependidikan. Pendidikan guru pada LPTK program S1 antara lain bertujuan menghasilkan calon guru yang menguasai pengetahuan dasar mengenai ilmu yang diajarkannya secara konprehensif, mantap dan cukup mendalam sehingga para lulusan dapat mengembangkan dan menyesuaikan diri dengan berbagai situasi dan perubahan yang terjadi di tempat tugasnya. Sebelum menjadi guru, semua calon guru dilatih dan dibekali dengan hal-hal yang berkaitan dengan profesi keguruan pada suatu program pengalaman lapangan (PPL) (Tim, 2013).

Karena PPL merupakan muara dari segenap kemampuan yang telah diperoleh mahasiswa selama belajar di LPTK, maka keberhasilan mahapeserta didik calon guru dalam kegiatan PPL, mengisyaratkan keberhasilan mereka dalam mengemban profesi keguruan kelak setelah mereka memangku jabatan keguruan. Walaupun guru baru pernah mengikuti program PPL dan telah dinyatakan lulus dengan nilai baik, namun setelah bertugas beberapa tahun di sekolah tetap memiliki kelemahan-kelemahan. Kelemahan tersebut dapat terlihat dalam : (1) dalam proses belajar-mengajar, guru kurang dapat menerapkan metode mengajar yang bervariasi dan kurang menguasai teknik bertanya, (2) guru kurang mampu mengontrol suasana kelas, (3) guru jarang menggunakan alat bantu mengajar, karena kurang mampu memilih alat bantu yang sesuai dengan materi pelajaran tertentu dan tingkat intelektual peserta didik, (4) guru kurang memberikan kesempatan kepada peserta didik untuk bertanya, (5) guru mengalami kesulitan dalam menentukan peserta didik yang sudah mengerti dan belum mengerti tentang materi yang telah dia- 
jarkan (Mulyasa, 2007).

Oleh sebab itu pembekalan praktis kependidikan bagi mahasiswa calon guru di LPTK mutlak diperlukan untuk meningkatkan kompetensi calon guru ketika terjun di dunia pendidikan (Tim, 2010). Pembekalan ini dapat dilakukan melalui berbagai kegiatan, diantaranya melalui praktik pengajaran secara mikro (microteaching) maupun melalui praktik mengajar secara riil di sekolah (Praktik Pengalaman Lapangan/PPL). Kegiatan PPL bagi mahasiswa calon guru pada Program Studi Tadris Kimia Fakultas Tarbiyah IAIN Walisongo, mencakup berbagai kegiatan kependidikan di sekolah baik kegiatan intra kurikuler maupun ekstra kurikuler. Memahami berbagai kegiatan kependidikan di sekolah dimaksudkan agar para mahasiswa calon guru dapat memahami dinamika yang terjadi di sekolah secara langsung, sehingga kelak mereka tidak canggung lagi ketika menjadi guru yang sesungguhnya. Mengingat kegiatan PPL banyak berhubungan dengan interaksi terhadap warga sekolah (termasuk siswa, guru dan staf) yang dinamikanya terkadang tidak dapat diprediksi, maka mahasiswa perlu mempersiapkan mental dan fisiknya dengan baik agar tidak mengalami berbagai hambatan dalam melaksanakannya.

Keberhasilan mahasiswa calon guru dalam melaksanakan PPL dipengaruhi oleh banyak faktor salah satu diantaranya adalah keterampilan dasar mengajar calon guru dalam menghadapi situasi pembelajaran nyata di kelas, terutama yang berkaitan dengan interaksi dengan siswa. Keterampilan Dasar Mengajar merupakan keterampilan yang harus dimiliki oleh guru untuk mentransfer pengetahuan, keterampilan, sikap, dan nilai kepada siswa dalam proses pembelajaran. Keterampilan dasar mengajar merupakan keterampilan yang kompleks. Keterampilan dasar mengajar sangat berperan dalam keberhasilan kegiatan belajar mengajar (Turney, 1973). Meskipun para mahasiswa calon guru telah memiliki bekal teori dan praktik yang memadai mengenai keterampilan dasar mengajar, namun secara teknis berhadapan dengan siswa secara riil dalam pembelajaran di kelas bagi mereka merupakan hal yang baru. Dengan demikian, melalui kegiatan PPL kependidikan di sekolah, mahasiswa calon guru mendapat kesempatan yang luas untuk mengasah keterampilan 
dasar mengajar yang mereka miliki (TIM, 2013). Sebagai seorang calon guru kimia tingkat penguasaan keterampilan dasar mengajar dan kesiapan terhadap kegiatan PPL ini mutlak diperlukan sebagai modal awal menjadi calon guru yang profesional dan berkompeten dibidangnya, selain itu juga untuk mewujudkan proses pembelajaran yang efektif dengan output yang lebih baik. Berdasarkan uraian di atas maka penulis tertarik untuk mengadakan penelitian dengan judul "Analisis Keterampilan Dasar Mengajar Mahasiswa Calon Guru Kimia (Studi pada Praktik Pengalaman Lapangan Mahasiswa Tadris Kimia)".

\section{METODE PENELITIAN}

Penelitian ini merupakan penelitian deskriptif-kualitatif. Penelitian dilaksanakan di Program Studi Tadris Kimia Fakultas Tarbiyah IAIN Walisongo Semarang dengan melibatkan 28 orang mahasiswa yang mengikuti mata kuliah PPL (Praktik Pengalaman Lapangan). Penelitian ini bertujuan untuk mengetahui tingkat penguasaan keterampilan dasar mengajar calon guru Tadris Kimia Fakultas Tarbiyah IAIN Walisongo pada kegiatan Praktik Pengalaman Lapangan (PPL).

Data dalam penelitian ini dikumpulkan dengan metode dokumentasi dan metode observasi. Data keterampilan dasar mengajar calon guru kimia diambil pada saat mahasiswa tadris kimia melaksanakan pembelajaran langsung di kelas (PPL). Lembar observasi yang digunakan bentuk rating scale (skala 1-5). Keterampilan dasar mengajar mahasiswa yang dinilai dalam pelaksanaan praktik mengajar dikelas meliputi: (1) Keterampilan bertanya, (2) Keterampilan memberi penguatan, (3) Keterampilan mengadakan variasi, (4) Keterampilan menjelaskan, (5) Keterampilan membuka menutup pelajaran, (6) Keterampilan membimbing diskusi, (7) Keterampilan mengelola kelas, (8) Keterampilan mengajar kelompok kecil. Dari tiap aspek dalam penilaian keterampilan dasar mengajar pada lembar observasi yang sudah diubah menjadi nilai kuantitatif, diubah menjadi nilai kualitatif dengan kriteria penilaian ideal dengan ketentuan yang terdapat pada tebel 1 . 
Tabel 1.

Kriteria Penilaian Ideal

\begin{tabular}{|c|c|c|}
\hline No & Rentang Skor & Kategori \\
\hline 1. & $\mathrm{X}>\mathrm{Mi}+1,5 \mathrm{SBi}$ & Sangat Baik \\
\hline 2. & $\mathrm{Mi}+0,5 \mathrm{SBi}<\mathrm{X} \leq \mathrm{Mi}+1,5 \mathrm{SBi}$ & Baik \\
\hline 3. & $\mathrm{Mi}-0,5 \mathrm{SBi}<\mathrm{X} \leq \mathrm{Mi}+0,5 \mathrm{SBi}$ & Cukup \\
\hline 4. & $\mathrm{Mi}-1,5 \mathrm{SBi}<\mathrm{X} \leq \mathrm{Mi}+-0,5 \mathrm{SBi}$ & Kurang \\
\hline 5. & $\mathrm{X} \leq \mathrm{Mi}-1,5 \mathrm{SBi}$ & Sangat Kurang \\
\hline
\end{tabular}

(Sudijono, 1987)

Keterangan:

X : Skor rata-rata

Mi : Rata-rata ideal

: $1 \frac{1}{2}($ skor maksimal ideal + skor minimal ideal $)$

SBi : Simpangan Baku

:1/6 ( skor maksimal ideal - skor minimal ideal )

Skor maksimal ideal $\quad=\sum$ butir $\mathrm{x}$ skor tertinggi

Skor minimal ideal $\quad=\sum$ butir $\mathrm{x}$ skor terendah

$$
\text { Persentase penilaian }=\frac{\text { Skor rata }- \text { rata }}{\text { Skor Maksimal }} \times 100 \%
$$

Persentase penilaian ketrampilan dasar mengajar mahasiswa Tadris Kimia dihitung dengan menggunakan rumus (Furqan, 1997):

Tabel 2. Kategori Persentase Penilaian

\begin{tabular}{|c|c|}
\hline Rata-rata Nilai Kelas & Kategori \\
\hline $80 \%<x \leq 100 \%$ & Sangat baik \\
$67 \%<x \leq 80 \%$ & Baik \\
$53 \%<x \leq 67 \%$ & Cukup \\
$40 \%<x \leq 53 \%$ & Jelek \\
$x<40 \%$ & Sangat Jelek \\
\hline
\end{tabular}




\section{HASIL DAN PEMBAHASAN}

\section{Hasil Analisis}

Delapan keterampilan dasar mengajar mahasiswa diamati dan dianalisis pada pelaksanaan Praktik Pengalaman Lapangan meliputi (1) Keterampilan bertanya, (2) Keterampilan memberi penguatan, (3) Keterampilan mengadakan variasi, (4) Keterampilan menjelaskan, (5) Keterampilan membuka dan menutup pelajaran, (6) Keterampilan membimbing diskusi kelompok kecil, (7) Keterampilan mengelola kelas, (8) Keterampilan mengajar kelompok kecil dan perorangan. Penentuan penilaian keterampilan dasar mengajar mahasiswa calon guru didasarkan pada asumsi standar ideal (kurva normal), yaitu membandingkan dengan skor ideal. Kriteria penilaian ideal kesiapan mengajar dapat dilihat pada tabel 3.

\section{Tabel 3.}

Kriteria Penilaian Ideal Keterampilan Dasar Mengajar

\begin{tabular}{|c|c|c|}
\hline No & Rentang Skor & Kategori \\
\hline 1. & $X>252$ & Sangat Baik \\
\hline 2. & $210<X \leq 252$ & Baik \\
\hline 3. & $168<X \leq 210$ & Cukup \\
\hline 4. & $126<X \leq 168$ & Kurang \\
\hline 5. & $X \leq 126$ & Sangat Kurang \\
\hline
\end{tabular}

Berdasarakan analisis data keseluruhan keterampilan dasar mengajar didapatkan bahwa skor total keterampilan dasar mengajar adalah $6138(\mathrm{~N}=28))$, sehingga didapatkan skor rata-rata keterampilan dasar mengajar adalah 219,21. Skor rata-rata sebesar 219,21, sehingga jika dimasukkan dalam tabel kriteria penilaian ideal maka keterampilan dasar mengajar mahasiswa Tadris Kimia berada pada rentang skor $210<X \leq 252$ dengan kategori baik. Persentase penilaian keterampilan dasar mengajar mencapai 69,59\% dengan kategori baik.

Setiap keterampilan yang terdapat dalam delapan keterampilan dasar mengajar dianalisis untuk mengetahui ketrampilan mana yang termasuk kategori sangat baik, baik, cukup baik, kurang, san- 
gat kurang. Hasil analisis kedelapan kompetensi dalam kesiapan mengajar dapat dirangkum dalam tabel 4.

\section{Tabel 4.}

Penilaian setiap Aspek dalam Keterampilan Dasar Mengajar

\begin{tabular}{|l|c|c|c|c|c|}
\hline \multicolumn{1}{|c|}{ Keterampilan dasar mengajar } & $\begin{array}{c}\text { Skor } \\
\text { total }\end{array}$ & $\mathbf{N}$ & $\begin{array}{c}\text { Skor } \\
\text { Rata- } \\
\text { rata }\end{array}$ & Kriteria & $\begin{array}{c}\text { \% Pe- } \\
\text { nilaian }\end{array}$ \\
\hline 1. Keterampilan Bertanya & 668 & 28 & 23,86 & Baik & 68,16 \\
\hline 2. Keterampilan Menjelaskan & 745 & 28 & 26,61 & Cukup & 66,52 \\
\hline $\begin{array}{l}\text { 3. Keterampilan Membuka dan Menu- } \\
\text { tup Pembelajaran }\end{array}$ & 612 & 28 & 21,86 & Baik & 72,86 \\
\hline $\begin{array}{l}\text { 4. Keterampilan Mengajar Kelompok } \\
\text { Kecil dan Perorangan }\end{array}$ & 1799 & 28 & 64,25 & Baik & 71,39 \\
\hline 5. Keterampilan Mengelola Kelas & 653 & 28 & 23,32 & Cukup & 66,63 \\
\hline 6. Keterampilan memberi penguatan & 519 & 28 & 18,54 & Baik & 74,14 \\
\hline 7. Keterampilan Membimbing Diskusi & 688 & 28 & 24,57 & Baik & 70,20 \\
\hline 8. Keterampilan Mengadakan Variasi & 454 & 28 & 16,21 & Cukup & 64,86 \\
\hline
\end{tabular}

\section{Pembahasan}

Di dalam penelitian ini, keterampilan dasar mengajar mahasiswa diamati dan dinilai pada pelaksanaan Praktik Pengalaman Lapangan. Berdasarkan analisis keterampilan dasar mengajar yang meliputi (1) Keterampilan bertanya, (2) Keterampilan memberi penguatan, (3) Keterampilan mengadakan variasi, (4) Keterampilan menjelaskan, (5) Keterampilan membuka dan menutup pelajaran, (6) Keterampilan membimbing diskusi kelompok kecil, (7) Keterampilan mengelola kelas, (8) Keterampilan mengajar kelompok kecil dan perorangan, didapatkan bahwa secara keseluruhan mahasiswa tadris kimia mempunyai keterampilan dasar mengajar yang baik dalam pelaksanaan PPL dengan persentase penilaian keterampilan mengajar mencapai 69,59\%.

Keterampilan dasar mengajar (teaching skills) adalah kemampuan atau keterampilan yang bersifat khusus (most specific instructional behaviors) yang harus dimiliki oleh guru, dosen, instruktur atau widyaiswara agar dapat melaksanakan tugas mengajar secara 
efektif, efisien dan profesional (As. Gilcman,1991).

1. Keterampilan Bertanya (Questioning skills)

Persentase penilaian keterampilan bertanya mahasiswa Tadris Kimia diperoleh skor rata-rata dibagi dengan skor maksimal dikalikan seratus persen. Pada penelitian ini persentase penilaian keterampilan bertanya mahasiswa Tadris Kimia mencapai $68,16 \%$. Nilai ini termasuk kategori baik. Keterampilan bertanya yang baik memainkan peranan penting, hal ini dikarenakan pertanyaan yang tersusun dengan baik dan teknik melontarkan pertanyaan yang tepat akan memberikan dampak positif terhadap siswa, yiatu: meningkatkan pastisipasi siswa dalam kegiatan pembelajaran. Dan membangkitkan minat dan rasa ingin tahu siswa terhadap sesuatu masa-lah yang sedang dibicarakan (Uzer Usman, 1992).

2. Keterampilan Menjelaskan (Explaning skills)

Keterampilan menjelaskan mahasiswa calon guru kimia berada dalam kategori cukup baik, dengan persentase penilaian $66,52 \%$. Dalam kaitan dengan kegiatan belajar mengajar- mengajar, menjelaskan berarti mengorganisasikan materi pelajaran dalam tata urutan yang terencana secara sistimatis, sehingga dengan mudah dapat dipahami oleh siswa definisi ini dapat dipahami bahwa keterampilan menjelaskan mutlak perlu dimiliki oleh para guru calon guru kimia.

3. Keterampilan Membuka dan Menutup Pelajaran (Set Induction and Closure Skills)

Keterampilan membuka dan menutup pelajaran mahasiswa calon guru kimia adalah baik, dengan persentase penilaian $72,86 \%$. Keterampilan membuka pelajaran akan merupakan awal keberhasilan seorang guru karena kiat membuka pelajaran sangat menentukan termotivasi tidaknya siswa dalam mengikuti pembelajaran. Jadi ketika mahasiswa calon guru kimia memiliki keterampilan yang baik dalam membuka pelajaran maka akan menentukan keberhasilan kegiatan pembelajaran selanjutnya, karena siswa sudah termotivasi. Sedangkan keterampilan menutup pelajaran menentukan tingkat pemantapan pembelajaran yang dilakukan. Perlu tekankan bahwa ke- 
giatan membuka dan menutup pelajaran tidak saja dilakukan pada awal dan akhir kegiatan, tetapi juga pada awal dan akhir setiap penggal kegiatan, dengan catatan bahwa kegiatan ini harus bemakna dan berkesinambungan.

4. Keterampilan Mengajar Kelompok Kecil dan Perorangan

Keterampilan mengajar kelompok kecil dan perorangan mahasiswa calon guru kimia berada dalam kategori baik, dengan persentase penilaian $71,39 \%$.

Penguasaan keterampilan mengajar kelompok kecil dan individual memungkinkan calon guru kimia mengelola kegiatan jenis ini secara efektif dan efesien serta memainkan perannya sebagai organisator kegiatan belajar-mengajar, Sumber informasi bagi siswa, pendorong bagi siswa untuk belajar, penyedia materi dan kesempatan belajar bagi siswa, pendiagnosa dan pemberi bantuan kepada siswa sesuai dengan kebutuhannya, serta peserta kegiatan yang punya hak dan kewajiban seperti peserta lainnya.

5. Keterampilan Mengelola Kelas

Keterampilan mengelola kelas mahasiswa calon guru kimia berada dalam kategori cukup baik, dengan persentase penilaian 66,63\%. Menurut Woolfolk, keberhasilan guru dalam pembelajaran, di samping ditentukan oleh pengetahuan guru tentang bahan ajar dan metode mengaiar juga ditentukan oleh pengelolalan kelas. Oleh karena itu, kemampuan guru dalam mengelola pembelajaran menjadi hal yang penting karena berkaiatan langsung denganaktivitas belajar siswa dikelas.

Guru harus berupaya memikirkan dan membuat perencanaan secara seksama untuk meningkatkan kualitas pembelajaran dan kesempatan belajar bagi siswanya. Mulyasa (2010) menjelaskan bahwa pembelajaran merupakan suatu proses yang kompleks yang melibatkan berbagai aspek yang saling terkait satu dengan yang lain. Aspek-aspek yang saling berkaitan tersebut, antara lain: guru, siswa, vahan ajar, sarana pembelajaran dan lingkungan belajar. Mengorganisir dalam pembelajaran adalah pekerjaan yang dilakukan seorang guru dalam mengatur dan menggunakan sumber belajar dengan maksud menca- 
pai tujuan belajar dengan cara efektif dan efisien.

Seorang calon guru kimia dituntut mampu mengelola kelas yaitu menciptakan dan mempertahankan kondisi belajar yang optimal bagi tercapainya tujuan pengajaran. Menurut Pidarta (1980) "Pengelolaan kelas adalah upaya yang dilakukan oleh guru dalam menciptakan dan mempertahankan serta mengembang tumbuhkan motivasi belajar untuk mencapai tujuan yang telah di tetapkan". Sedangkan menurut Usman (2003) "Pengelolaan kelas yang efektif merupakan prasyarat mutlak bagi terjadinya proses belajar mengajar yang efektif".

6. Keterampilan Memberi Penguatan (Reinforcement Skills)

Keterampilan mengajar memberi penguatan mahasiswa calon guru kimia berada dalam kategori baik, dengan persentase penilaian $74,14 \%$. Penguatan adalah segala bentuk respon apakah bersifat verbal (diungkapkan dengan kata-kata langsung seperti: bagus, pintar, ya, betul, tepat sekali, dan sebagainya), maupun nonverbal (biasanya dilakukan dengan gerak, isyarat, pendekatan, dan sebagainya) merupakan bagian dari modifikasi tingkah laku guru terhadap tingkah laku siswa yang bertujuan untuk memberikan informasi atau umpan balik (feedback) bagi siswa atas perbuatannya sebagai suatu tindak dorongan atau koreksi. Seorang calon guru kimia perlu menguasai keterampilan memberikan penguatan karena penguatan merupakan dorongan bagi siswa untuk meningkatkan perhatiannya.

7. Keterampilan Membimbing Diskusi

Keterampilan mengelola kelas mahasiswa calon guru kimia berada dalam kategori baik, dengan persentase penilaian $70,20 \%$. Dalam keterampilan ini mahasiswa calon guru harus terampil memotivasi seluruh siswa agar memberi kesempatan semua siswa untuk berpartisipasi (tidak terlalu didominasi pembicaraan, dan tidak terlalu pasif). Keterampilan membimbing diskusi menuntut mahasiswa calon guru untuk membimbing/mengarahkan diskusi agar tetap menuju masalah yang dibahas, serta terampil mendengarkan dan merumuskan hasilhasil diskusi kelompok (Hasibuan dkk. 1991). 
8. Keterampilan Mengadakan Variasi

Keterampilan mengadakan variasi mahasiswa calon guru kimia berada dalam kategori baik, dengan persentase penilaian $64,86 \%$. Variasi stimulus adalah suatu kegiatan guru dalam konteks proses interaksi pembelajaran yang ditujukan untuk mengatasi kejenuhan siswa, sehingga dalam situasi belajar mengajar, siswa menunjukkan ketekunan, antusiasme serta penuh partisipasi. Keterampilan mengadakan variasi yang baik bagi calon guru kimia sangat berguna pada saat praktik mengajar, karena kegiatan mengadakan variasi di kelas dapat motivasi para siswa, serta mengarungi kejenuhan dan kebosanan (Marno dan Idris, 2008)

Keterampilan dasar mengajar mahasiswa Tadris Kimia yang paling menonjol adalah keterampilan memberi penguatan $(74,14 \%)$, sedangkan keterampilan yang paling rendah adalah keterampilan mengadakan variasi $(64,86 \%)$ tetapi masih dalam kategori baik. Keterampilan mengadakan variasi dalam pembelajaran mahasiswa Tadris Kimia masih kurang dikarenakan mahasiswa masih mengalami kesulitan memilih metode dan strategi yang sesuai relevan dengan kompetensi dasar. Metoda dan strategi pembelajaran yang dipilih pada umumnya bersifat ceramah aktif, dominansi guru menonjol, sedikit sekali kegiatan yang mengajak siswa merumuskan hipotesis, bereksperimen, mengumpulkan data, menganalisis, menginterpretasi data, dan menarik kesimpulan berdasarkan bukti.

\section{KESIMPULAN}

Keterampilan dasar mengajar Mahasiswa Tadris Kimia pada pelaksanaan PPL secara keseluruhan adalah baik dangan persentase penilaian mencapai $69,59 \%$. Keterampilan dasar mengajar mahasiswa Tadris Kimia yang paling menonjol adalah keterampilan memberi penguatan $(74,14 \%)$, sedangkan keterampilan yang paling rendah adalah keterampilan mengadakan variasi $(64,86 \%)$. 
Mulyatun

\section{DAFTAR PUSTAKA}

Furqan. 1997. Statistika Terapan untuk Penelitian. Bandung: CV AlFABETA

Hasibuan dkk. 1991. Prinsip Belajar Mengajar: Keterampilan Dasar Pengajaran Mikro. Bandung: Remaja Rosda Jaya.

Marno dan Idris. 2008. Strategi dan Metode Pengajaran: Menciptakan Keterampilan Mengajar yang Efektif dan Edukatif. Yogyakarta: Ar-Ruzz Media.

Mulyasa, E. 2007. Standar Kompetensi dan Sertifikasi Guru. Bandung:Rosdakarya

Pidarta, Made. 1980. Pengelolaan Kelas. Usaha Nasional: Surabaya

Sudijono, Anas. 1987. Pengantar Statistika Pendidikan. Jakarta: CV Rajawali

Tim Penyusun .2010. Panduan Praktik Pembelajaran Micro. UPPL UNY

Tim. 2013. Buku Panduan Praktik Pengalaman Lapangan. Semarang: Fakultas Tarbiyah IAIN Walisongo.

Turney, C.dkk. 1973. Sydney Micro Skills Handbook Series 1-5. Sidney:Sydney University

Undang-undang Nomor 14 tentang Guru dan Dosen serta Standar Nasional Pendidikan Tahun 2005. Jakarta: CV. Tamita Utama.

Usman, Moh. Uzer. 2002. Menjadi Guru Profesional. Bandung : Remaja Rosda Karya. 